Published December 2018

\title{
Berbagai Konsep Hilal di Indonesia
}

\author{
Abu Yazid Raisal \\ Universitas Ahmad Dahlan Yogyakarta \\ Email: abuyazidraisal@gmail.com
}

\begin{tabular}{|c|c|}
\hline Abstract & Artikel Info \\
\hline $\begin{array}{l}\text { The issue of the initial stipulation of the month (especially } \\
\text { Ramadan, Shawwal and Zulhijah) in Indonesia to this day } \\
\text { has not ended. One reason for the problem of defining the } \\
\text { new moon. Admittedly in Indonesia there are a variety of } \\
\text { views and opinions regarding the definition of the new } \\
\text { moon which between one another seems contradictory. } \\
\text { Nahdlatul Ulama defines the hilal to be visible (ruukyat), } \\
\text { Muhammadiyah defines enough by reckoning, and the } \\
\text { Ministry of Religion (Government) defines the possibility of } \\
\text { being seen (let rukyat). Each of these views has advantages } \\
\text { and disadvantages, and each of them has a syar'i's basic } \\
\text { foundation and their respective knowledge. } \\
\text { Keywords: Hilal, Beginning of The Month, Reckoning }\end{array}$ & $\begin{array}{c}\text { Received: } \\
15 \text { September } 2018 \\
\text { Revised: } \\
13 \text { Oktober } 2018 \\
\text { Accepted: } \\
20 \text { November } 2018\end{array}$ \\
\hline Abstrak & \\
\hline $\begin{array}{l}\text { Persoalan penetapan awal bulan (khususnya Ramadhan, } \\
\text { Syawal dan Zulhijah) di Indonesia sampai hari ini tak } \\
\text { kunjung usai. Salah satu sebab persoalan pendefinisian hilal. } \\
\text { Diakui di Indonesia terdapat ragam pandangan dan pendapat } \\
\text { mengenai definisi hilal ini yang mana antara satu dengan } \\
\text { yang lain tampak bertentangan. Nahdlatul Ulama } \\
\text { mendefinisikan hilal harus terlihat (ruukyat), } \\
\text { Muhammadiyah mendefinisikan cukup dengan perhitungan } \\
\text { (hisab), dan Kementerian Agama (Pemerintah) } \\
\text { mendefinikan dengan kemungkinan terlihat (imkan rukyat). } \\
\text { Masing-masing pandangan ini memiliki kelebihan dan } \\
\text { kekurangan, dan masing-masing memiliki landasan dalil } \\
\text { syar'i dan ilmi masing-masing. } \\
\text { Kata Kunci: Hilal, Awal Bulan, Hisab-Ruyat }\end{array}$ & \\
\hline
\end{tabular}

\section{A. Pendahuluan}

Penanggalan dalam Islam

ditetapkan dengan sistem bulan

(qamary) yaitu dengan munculnya hilal,

baik dengan rukyat maupun hisab. Satu bulan kamariah adalah jangka waktu yang dihabiskan bulan dalam fasefasenya hingga sempurna selama 29 hari 12 jam 44 menit 2,9 detik. Dimana bulan senantiasa bertukar kedudukan 
AL-MARSHAD: JURNAL ASTRONOMI ISLAM DAN ILMU-ILMU BERKAITAN

ISSN 2442-5729 (print) || ISSN 2598-2559 (online), http://jurnal.umsu.ac.id/index.php/almarshad

DOI: $10.30596 /$ jam.v4i2.2478

Published December 2018

dipandang dari arah bumi yang menyebabkan bentuk bulan bertukar dalam fase-fasenya yang diistilahkan dengan aujuh al-qamar atau phases of the moon.

\section{Perbedaan dan perdebatan} seputar hisab dan rukyat telah demikian rutin terjadi di Indonesia khususnya menjelang puasa dan hari raya. Persoalan ini bila dipandang secara teknis ilmiah sebenarnya tergolong mudah karena merupakan bagian ilmu eksakta. T tapi dalam penerapannya di masyarakat tidak sederhana, karena menyangkut faktor-faktor non-eksakta seperti perbedaan pandangan hukum (mazhab dan fikih). Dalam makalah ini akan dibahas berbagai konsep dan metode hisab sebagai berkembang di Indonesia dengan segala fenomena dan paradigmanya.

\section{B. Bumi, Matahari dan Bulan}

Bumi, Bulan dan Matahari adalah tiga benda angkasa ciptaan Allah yang dari tiga fenomena ini manusia dapat beraktifitas, termasuk di dalamnya aktifitas ibadah. Pemahaman yang baik terhadap tiga benda angkasa ini sejatinya akan mempermudah pemahaman tentang penetapan awal bulan kamariah yang rutin dibicarakan dan diperdebatkan setiap tahun.

Bumi memerlukan masa berputar pada sumbunya (rotasi) selama 23 jam 56 menit 05,09054 detik yang menyebabkan terjadinya siang dan malam. Disamping berputar pada sumbunya, bumi juga bergerak mengelilingi matahari (revolusi) dengan kecepatan yang tidak teratur selama 365,2425 atau 365 1/4 hari, yang mengakibatkan siklus tahunan. ${ }^{1}$ Dalam rotasinya pula, bumi akan miring membentuk sudut 23,5 derajat terhadap garis bidang orbitnya mengelilingi matahari, yang menyebabkan adanya empat tatanan musim di bumi yaitu musim hujan, kemarau, semi dan gugur.

Matahari adalah satu diantara bintang-bintang di jagat raya, matahari merupakan bintang terdekat dengan bumi hingga menyebabkan banyak penelitian tentangnya. Matahari merupakan objek penelitian astronomi utama yang selalu menakjubkan, ia berupa bola gas raksasa panas berdiameter sekitar 1,4 juta kilometer, atau 100 kali lipat lebih dari bumi.

\footnotetext{
1 Erlina Hasan, Penanggalan (Tarikh), Diktat Mata Kuliah Ilmu Falak Fakultas Syari'ah Universitas Islam Sumatera Utara (UISU), (Medan, t.t.), h.5.
} 
Matahari juga adalah sumber kehidupan utama manusia, manusia dapat beraktifitas dan bahkan beribadah disebabkan adanya rutinitas alamiah matahari. Dalam peredarannya, matahari melintasi ekuator dalam setahun sebanyak dua kali, yaitu sekitar tanggal 21 Maret dan 23 September. Satu tahun Matahari adalah jangka waktu yang diperlukan oleh Bumi untuk mengelilingi matahari (revolusi), ratarata satu tahun lamanya $3651 / 4$ hari. $^{2}$

$$
\text { Sedangkan bulan, dalam }
$$
peredarannya berputar mengelilingi bumi sekali dalam sebulan, yang sering disebut satu lunasi (satu siklus fase Bulan) atau satu perioda revolusi sinodik, yaitu 29 hari 12 jam 44 menit 2,9 detik atau 29.530589 hari, yang berarti masa satu tahunnya 354 hari 8 jam 48 menit 35 detik $(354,3670694$ hari). Bulan-bulan kamariah terjadi melalui siklus peredaran yang dihabiskan bulan satu kali peredaran sempurna dari munculnya hilal hingga muncul hilal berikutnya atau dari satu konjungsi ke konjungsi berikutnya. Dalam penggunaan sehari-hari, angka

2 Farid Ruskanda, APU, 100 Masalah Hisab dan Rukyat, Telaah Syari'ah, Sains dan Teknologi, (Yogyakarta: Gema Insani Press, 1416 H-1996 M), h. 13-14 pecahan bulan (yaitu 0,530589) tidaklah praktis, maka dibulatkan dengan berganti-ganti antara 30 hari dan 29 hari, hal ini senada dengan hadis baginda Nabi Saw yang menyatakan bulan itu adakalanya 30 hari, adakalanya pula 29 hari".

\section{Karakteristik Bulan Kamariah}

Perubahan penampakan wajah bulan setiap harinya, seperti yang terlihat dari bumi adalah sebagai akibat posisi relatif bulan terhadap bumi dan matahari. Wajah bulan tampak berbeda dari waktu ke waktu yang disebut fasefase Bulam. Fase-fase tersebut adalah: crescent (hilal), first quarter (at tarbi' al awwal), first Gibbous (al ahdab al awwal), full Moon (al badar), second gibbous (al-ahdab ats- tsany), second quarter (at- tarbi' ats-tsany), Second Crescent (al-hilal ats-tsany), dan Wane (al-mahaq) atau disebut juga fase konjungsi atau ijtimak.

Konjungsi atau ijtimak merupakan syarat awal masuknya bulan baru kamariah secara astronomis, yaitu saat bulan berada diantara matahari dan bumi, dimana wajah bulan tidak nampak dari bumi. Ijtimak atau konjungsi adalah pertemuan atau 
AL-MARSHAD: JURNAL ASTRONOMI ISLAM DAN ILMU-ILMU BERKAITAN

ISSN 2442-5729 (print) || ISSN 2598-2559 (online), http://jurnal.umsu.ac.id/index.php/almarshad

DOI: 10.30596/jam.v4i2.2478

Published December 2018 berimpitnya dua benda yang berjalan secara aktif yang terletak pada posisi garis bujur yang sama bila dilihat dari arah timur ataupun arah barat. Para saintis dan sebagian ulama sepakat bahwa ijtimak atau konjungsi merupakan syarat utama masuknya awal bulan kamariah.

Selanjutnya, hilal yang merupakan acuan utama terhadap masuknya awal bulan memiliki beberapa karakteristik, yaitu:

1. Bulan terbenam lebih dahulu dari matahari (hilal masih atau sudah berada dibawah ufuk, alias hilal negatif). Dalam keadaan ini, hilal dipastikan tidak terlihat, dan setiap kesaksian akan tertolak.

2. Matahari terbenam lebih dahulu dari bulan. Dalam keadaan ini, ada kemungkinan hilal terlihat, namun bergantung ketinggiannya di atas ufuk.

3. Hilal terlihat setelah terbenamnya matahari sebelum terjadi konjungsi. Hal ini belum terhitung sebagai hilal awal bulan dan masih terhitung sebagai hilal akhir bulan (fenomena ini terhitung ganjil dan jarang terjadi).
4. Terjadinya konjungsi ketika terbenamnya Matahari dalam keadaan tertutup (kasyifah) alias terjadi gerhana matahari, maka dipastikan hilal tidak akan terlihat karena kekontrasan cahaya Matahari.

5. Bulan terbenam setelah terbenamnya Matahari, sementara itu di wilayah lain sebaliknya (dalam satu wilayah kesatuan negara). Maka dalam hal ini, setiap wilayah berlaku penetapan masingmasing berlandaskan pada hadis Kuraib.

\section{Kesaksian (Syahadah) dalam Rukyat}

Mazhab Hanafi

Dalam aktifitas rukyat, kalangan Hanafiyah menetapkan kriteria sebagai berikut: jika awan dalam keadaan cerah, maka disyaratkan rukyat kolektif (ru'yah jama'ah) dan tidak dapat diperpegangi kesaksian orang perorang menurut pendapat yang rajih, dengan alasan: dalam keadaan cuaca cerah tentu tidak ada penghalang bagi seseorang untuk tidak dapat melihat hilal sementara yang lain melihat. Namun jika hilal dalam keadaan tidak 
memungkinkan untuk dilihat karena mendung misalnya, maka mencukupilah kesaksian satu orang dengan syarat ia beragama Islam, adil, berakal dan dewasa. $^{3}$

\section{Mazhab Syafi'I dan Hanbali}

Syafi'iyah dan Hanabilah menetapkan: minimal dengan kesaksian (rukyat) satu orang baik cuaca dalam keadaan cerah atau mendung, dengan catatan si perukyat beragama Islam, dewasa, berakal, merdeka, laki-laki dan adil. Selanjutnya kesaksian (rukyat) tersebut dipersaksikan dihadapan kadi (pemerintah) bedasarkan hadis dari Ibnu Umar. ${ }^{4}$ Selanjutnya wajib pula terhadap orang yang melihat hilal untuk berpuasa meskipun tidak dipersaksikan dihadapan kadi (pemerintah), begitu pula terhadap orang yang percaya dan meyakininya meskipun orang yang melihat hilal tersebut anak-anak, wanita, hamba, orang fasik bahkan orang kafir sekalipun. ${ }^{5}$ Hal ini dalam rangka kehati-

\footnotetext{
${ }^{3}$ Abdurrahman al Jaziri, Kitab al Fiqh 'ala al Madzahib al Arba'ah, (Kairo: Mu'assasah alMukhtar, 2001), h.421.

${ }^{4}$ Muhammad bin Ali as Syaukani, Naylul Awthar, (Kairo: Dar Ibnul Haitsam-Kairo, tt.), h. 597

5 Abdurrahman al-Jaziri, Kitab al Fiqh 'ala al Madzahib al Arba'ah, h. 432
}

hatian dalam masuknya waktu ibadah (Ramadhan), sebab puasa pada Sya'ban lebih ringan dari berbuka di bulan Ramadhan.

\section{Mazhab Maliki}

Malikiyah menetapkan dengan tiga kriteria: Rukyat kolektif, Rukyat satu orang adil, dan Rukyat dua orang adil. Point (1) dan (2) dengan dalil terdahulu. Adapun rukyat dua orang adil berdasarkan hadis riwayat $\mathrm{Abu}$ Dawud dan Ahmad.

\section{Rukyat di Era Modern}

Seiring majunya zaman dan peradaban, tekstualis hadis dan pendapat-pendapat para ulama terdahulu mulai bergeser dan disinergikan dengan kondisi kekinian. Prof.Dr.Muhammad Ahmad Sulaiman (Guru Besar Astronomi di Ma'had al Qawmy lil Buhuts al Falakiyyah wal Geofiziqiyyah Helwan, Mesir) menyebutkan, terdapat beberapa kriteria yang harus terpenuhi demi sah dan berkualitasnya kesaksian rukyat secara syar'i dan 'ilmi, yaitu:

1. Sehat jasmani dan rohani (akal).

2. Jelas penglihatan.

3. Adil dan terpercaya. 
AL-MARSHAD: JURNAL ASTRONOMI ISLAM DAN ILMU-ILMU BERKAITAN

ISSN 2442-5729 (print) || ISSN 2598-2559 (online), http://jurnal.umsu.ac.id/index.php/almarshad DOI: 10.30596/jam.v4i2.2478

Published December 2018

4. Memahami teks dan konteks rukyat.

Terhadap point 1,2, dan 3, agaknya banyak orang yang mampu melakukannya, karena kelengkapan ini pada umumya dimiliki manusia. Namun khusus point 4, diperlukan kedetailannya, meliputi:

Pemahaman lapangan; area rukyat terideal adalah pinggir laut lepas dan bebas tanpa penghalang atau tempat yang tinggi. (2) Waktu rukyat; yaitu sejak terbenam matahari setelah terjadinya konjungsi. (3) Memahami keadaan teknis hilal; hilal tanggal satu adalah hilal yang tanduknya mengarah ke timur, jika sedikit mengarah ke bawah (barat) masih terhitung hilal akhir bulan, munculnya hilal disebelah barat, area munculnya hilal sejauh 8 derajat kesebelah kanan dan kiri matahari terbenam dan 15 derajat sebelah atas terbenamnya matahari.

Ringkasnya: apa, bagaimana, berapa lama, kapan dan dimana hilal itu ? Deretan pertanyaan teknis hilal ini perlu difahami secara baik oleh para perukyat, sebab kenyataan di lapangan banyak perukyat yang tidak memahami hal-hal teknis ini, yang terjadi hanya tunduk patuh terhadap literal hadis tanpa riset ilmiah. Hadis Nabi Saw memang sederhana, namun menuntut praktik tepat yang terkait dengan tiga fenomena alami benda angkasa (Bulan, Bumi dan Matahari). Rasulullah Saw memang tidak pernah menanyakan serinci dan seeksplisit ini, karena ketika itu sarana satu-satunya hanya pengamatan, dan sahabatpun lihai dan piawai dengan fenomena langit.

\section{E. Berbagai Konsep Hilal di Indonesia}

Rukyat NU

Sikap rukyat NU ditetapkan melalui proses yang panjang, diawali dari keputusan Muktamar NU XXVII di Situbondo tahun 1984, Munas Alim Ulama di Cilacap tahun 1987, Seminar Lajnah Falakiyah NU di Pelabuhan Ratu Sukabumi tahun 1992, Seminar Penyerasian Metode Hisab dan Rukyat di Jakarta tahun 1993, dan Rapat Pleno VI PBNU di Jakarta tahun 1993, berikutnya tertuang dalam Keputusan PBNU No. 311/A.II.04.d/1994 tertanggal 1 Sya'ban 1414 H/13 Januari 1994 M, dan Muktamar NU XXX di Lirboyo Kediri (1999). Keputusan PBNU tersebut terhimpun dalam sebuah 
AL-MARSHAD: JURNAL ASTRONOMI ISLAM DAN ILMU-ILMU BERKAITAN

ISSN 2442-5729 (print) || ISSN 2598-2559 (online), http://jurnal.umsu.ac.id/index.php/almarshad DOI: $10.30596 /$ jam.v4i2.2478

Published December 2018

buku berjudul "Pedoman Rukyat dan

Hisab Nahdlatul Ulama"6

NU berprinsip, hilal awal bulan Kamariah, khususnya RamadlanSyawal dan Dzulhijjah, didasarkan pada sistem rukyat, dimana hisab hanya sebagai pendukung. Pandangan ini didasarkan atas pemahaman bahwa nash-nash tentang rukyat tersebut bersifat tunduk patuh (ta'abbudy). Dimana QS. Al-Baqarah ayat 185 dan 189 dapat difahami sebagai perintah rukyat, dan didukung dengan banyak hadis-hadis terkait.

Sebagai konsekuensi dari prinsip tunduk patuh ini, NU tetap menyelenggarakan rukyat hilal di lapangan, betapapun menurut hisab hilal masih di bawah ufuk. Hal demikian dilakukan agar pengambilan keputusan, baik hilal terlihat atau istikmal, tetap didasarkan pada sistem rukyat di lapangan, bukan atas dasar prediksi hisab.

Wujudul Hilal dan Wilayatul Hukmi Muhammadiyah

6 Ahmad Ghazalie Masroeri, Penetapan Awal Bulan Kamariah Perspektif Nahdlatul Ulama, dalam Workshop Nasional Metodologi Penetapan Awal Bulan Qamariah Model Muhammadiyah, 2002, h. 1-2
Berbeda dengan NU, hilal yang didefinisikan Muhammadiyah adalah hilal yang sudah wujud di atas ufuk, yang dikenal dengan 'Wujudul Hilal'. Wujudul Hilal (kehadiran hakiki hilal) yang menjadi acuan Muhammadiyah memuat makna bahwa ketika bulan sudah berada di atas ufuk setelah terjadinya ijtimak dan setelah terbenamnya matahari (moon set terjadi sesudah sun set) berapapun ketinggiannya, berarti awal sebuah bulan kamariah sudah tiba.

Di dalam Himpunan Putusan Tarjih disebutkan: "ash-shaumu wal fithru bir ru'yah wala mani'a bil hisab" (puasa dan hari raya dengan rukyat, namun tidak mengapa menggunakan hisab). Statemen ini memuat pesan bahwa rukyat dan hisab berada dalam posisi yang seimbang tanpa ada dikotomi antara keduanya. Namun dalam realita empiriknya, Muhammadiyah tidak pernah melakukan rukyat dengan alasan rukyat itu sulit, Islam adalah agama yang menghargai kemajuan ilmu pengetahuan, dimana antara dimensi ideal wahyu dan peradaban manusia akan selalu berselaras. 
Dalam sejarahnya, setidaknya Muhammadiyah telah mengalami lima kali perubahan dan pengembangan keputusan ijtihadnya dalam masalah ini. Tiga diantaranya secara langsung terekam dalam Himpunan Putusan Tarjih yaitu dalan Bab Shiyam (puasa), Bab Masa'il Syatta (beberapa masalah) dan kitab Keputusan Wiradesa. Perubahan keempat terjadi pada tahun 2000 saat Munas Tarjih XXV di Jakarta. Perubahan terakhir dilakukan berdasarkan Keputusan Munas Tarjih XXVI tahun 2003 di Padang. ${ }^{7}$

Imkan Rukyat Kementerian Agama (Pemerintah)

\section{Kementerian}

Agama

(Pemerintah) mendefinisikan hilal minimal $2^{\circ}$ di atas ufuk, umur hilal minimal 8 jam setelah terjadinya ijtimak dan jarak lengkung bulan-matahari (sudut elongasi) minimal $3^{\circ}$. Kriteria ini dianggap sebagai penengah antara hisab dan rukyat, atau tepatnya antara NU dan Muhammadiyah. Pemerintah memberi batasan minimal $2^{\circ}$ sebagai pengakomodasian hisab dan rukyat,

\begin{tabular}{lllr}
\hline & Rahmadi & Wibowo, Hisab \\
Muhammadiyah; Konsep dan Aplikasi, Dalam & dar \\
Majalah Sinar & Muhammadiyah, edisi 41 \\
(Oktober 2007), h. 11
\end{tabular}

sebab hilal yang telah mencapai ketinggian $2^{\circ}$ memiliki kemungkinan dapat teramati dan secara astronomis telah berterima, karena dipastikan telah terjadinya konjungsi. Sikap pemerintah ini tertuang dalam Keputusan Majelis Ulama Indonesia (MUI) nomor 2 tahun 2004 tentang penetapan awal Ramadhan, Syawal dan Dzulhijjah. ${ }^{8}$

Namun tidak dipungkiri, banyak kalangan menilai kriteria ini tidak ilmiah dan terkesan ada pengabaian ilmu pengetahuan. Dalam konteks Indonesia, hilal dalam ketinggian $2^{\circ}$ sangatlah sulit untuk terlihat, disebabkan wilayah Indonesia yang basah dan tropis karena banyaknya lautan. Namun demikian, setidaknya sikap pemerintah ini menjadi alternatif bagi kalangan non NU dan non Muhammadiyah.

\section{F. Kesimpulan}

1. Penetapan puasa dan hari raya, khususnya di Indonesia, merupakan persoalan ijtihad sehingga memungkinkan terjadinya perbedaan pandangan

\footnotetext{
${ }^{8}$ Lihat Fatwa MUI nomor 2 tahun 2004 tentang penetapan awal Ramadhan, Syawal dan Dzulhijjah.
} 
dan pendapat. Beragamnya

kriteria hisab dan rukyat yang ada sejatinya hanyalah aplikasi dari ragam daya telaah dalil, bukan persoalan benar dan salah.

2. Teori wujudul hilal, imakn rukyat, dan rukyat adalah bangunan keilmuan yang tetap memiliki kekurangan dan senantiasa membuka ruang untuk ditinjau ulang, karena lazimnya sebuah teori ilmu, ia akan berubah seiring ditemukannya indikasi terkini yang teruji. Tidak ada satupun metode yang bersifat abadi dan mutlak, semuanya bersifat zhanny (prediksi). Rukyat (pengamatan) belum tentu benar, bisa jadi obyek yang disangka hilal sebenarnya bukan hilal. Hisab atas dasar Wujudul Hilal atau Imkan Rukyat dan model-model hisab lainnya juga belum tentu benar, masih ada yang bisa diperdebatkan baik secara sains dan terutama secara syariat.

3. Dalam konteks Indonesia, pengakomodasian maksimal rukyat dan hisab merupakan

syarat mutlak terwujudnya definisi tunggal hilal, jika satu diantaranya tidak terwakili maka selamanya hilal ilmiah dan syar'iyah tidak akan terwujud.

4. Bumi, bulan dan mataharia adalah tiga makhluk ciptaan Allah yang dari tiga benda angkasa ini manusia dapat beraktifitas termasuk di dalamnya aktifitas ibadah. Pemahaman yang baik terhadap tiga benda angkasa ini sejatinya mempermudah pemahaman tentang hisab dan rukyat dalam menentukan masuknya awal bulan kamariah.[]

\section{Daftar Pustaka}

al-Jaziri, Abdurrahman. (2001). Kitab al Fiqh 'ala al Madzahib al Arba'ah, Kairo: Mu'assasah alMukhtar.

Azhari, Susiknan. (2006). Menggagas Paradigma Baru Hisab di Muhammadiyah, Makalah dimuat dalam majalah Suara Muhammadiyah.

$\begin{array}{rrr}\text { Fatwa MUI Nomor } 2 \text { tahun } & 2004 \\ \text { tentang } & \text { penetapan awal }\end{array}$


AL-MARSHAD: JURNAL ASTRONOMI ISLAM DAN ILMU-ILMU BERKAITAN

ISSN 2442-5729 (print) || ISSN 2598-2559 (online), http://jurnal.umsu.ac.id/index.php/almarshad

DOI: $10.30596 /$ jam.v4i2.2478

Published December 2018

Ramadhan, Syawal dan

kuliah Ilmu Falak I dan II

Dzulhijjah.

Universita Islam Sumatera Utara.

Hasan, Erlina. (tt) Penanggalan

Wibowo, Rahmadi. (2007) Hisab

(Tarikh). Diktat Mata Kuliah Ilmu Muhammadiyah; Konsep dan

Falak Fakultas Syari'ah Aplikasi, Dalam Majalah Sinar

Universitas Islam Sumatera Utara Muhammadiyah.

(UISU). Medan.

Hasil hisab Majelis Tarjih dan Tajdid

PP Muhammadiyah 11 Rajab

1429 H/14 Juli 2008 tentang hisab awal Ramadhan, Syawal dan Dzulhijjah 1429 H.

Masroeri, Ahmad Ghazalie. (2002).

Penetapan Awal Bulan Kamariah

Perspektif Nahdlatul Ulama,

dalam Workshop Nasional

Metodologi Penetapan Awal

Bulan Qamariah Model

Muhammadiyah.

Ruskanda, S. Farid. (1996) 100

Masalah Hisab dan Rukyat,

Telaah Syari'ah, Sains dan

Teknologi, Gema Insani Press.

Sulaiman, Muhammad Ahmad. (2007)

Nahwa Shiyaghah Mabady' at

Taqwim al Islamy al 'Alamy,

Makalah Seminar Internasional

Tentang Kalender Islam di Jakarta

Indonesia.

TM. Ali Muda. (tt) Rumus Falak Sistem

Jean Meeus. Diktat rumus mata 